Relations industrielles

Industrial Relations

\title{
Drache, Daniel, and Harry Glasbeek, The Changing Workplace: Reshaping Canada 's Industrial Relations System
}

\section{Kenneth Wm. Thornicroft}

Volume 50, numéro 2, 1995

URI : https://id.erudit.org/iderudit/051021ar

DOI : https://doi.org/10.7202/051021ar

Aller au sommaire du numéro

Éditeur(s)

Département des relations industrielles de l'Université Laval

ISSN

0034-379X (imprimé)

1703-8138 (numérique)

Découvrir la revue

Citer ce compte rendu

Thornicroft, K. W. (1995). Compte rendu de [Drache, Daniel, and Harry

Glasbeek, The Changing Workplace: Reshaping Canada 's Industrial Relations

System]. Relations industrielles / Industrial Relations, 50(2), 449-451.

https://doi.org/10.7202/051021ar

Tous droits réservés @ Département des relations industrielles de l'Université Laval, 1995
Ce document est protégé par la loi sur le droit d'auteur. L’utilisation des services d'Érudit (y compris la reproduction) est assujettie à sa politique d'utilisation que vous pouvez consulter en ligne.

https://apropos.erudit.org/fr/usagers/politique-dutilisation/ 
l'infrastructure analytique demeure vieille. Tout au long des 396 pages de l'ouvrage, il s'avère excessivement difficile de glaner quelque chose de nouveau. L'anachronisme de l'ouvrage est à ce point criant que les conclusions brossées par les auteurs rejoignent au mieux, sans jamais les dépasser, celles d'une ribambelle de manuels scolaires américains publiés vingt ans auparavant. Qui plus est, le désagréable "sentiment de déjà vu " s'exacerbe davantage au contact d'ouvrages récents ayant poussé plus loin la réflexion de la dynamique individu-organisation. Par exemple, le collectif publié sous la direction de JeanFrançois Chanlat et intitulé L'individu dans l'organisation: les dimensions oubliées (1990) permet très bien de saisir l'obligation de sortir définitivement des sentiers battus afin d'accéder à une connaissance plus perspicace de la complexité de l'humain et du social. C'est ainsi qu'un regard sur les dimensions psychique, symbolique et spatio-temporelle aurait indubitablement permis une appréhension plus fine, subtile, congrue et complète de la vie des individus au travail.

Puis, l'ouvrage souffre d'un manque de synthèse. Il n'y a pas, ou trop peu, de réflexions critiques permettant d'extraire, des diverses descriptions syncrétiques, un fil conducteur liant entre elles les diverses notions théoriques abordées. Le manque de capsulage analytique mine considérablement tant la profondeur des réflexions que la portée des conclusions. En outre, la ténuité de l'exercice critique opéré par les auteurs se solde en définitive par la présentation " acontextuelle" des diverses constructions théoriques. À cet égard, les deux chapitres traitant de la motivation au travail (chapitres 7 et 8 ) détonnent étonnamment avec l'actuelle réalité sociétale et organisationnelle. Peut-on encore parler de motivation instrumentale (Maslow, Herzberg et Alderfer) dans un cadre organisationnel postmoderne où l'animation du psychisme (voir les travaux de Pagès, Enriquez, Lipovetsky, Ehrenberg et compagnie) revêt désormais un rôle incontournable? Peut-on encore aborder l'étude de la mobilisation instrumentale (approche socio-technique, QVT et qualité totale) dans une période de désengagement systématique des entreprises à l'endroit de leurs employés? En somme, parce qu'ils appartiennent à une autre époque, bon nombre des instruments conceptuels recensés et présentés par les auteurs ne parviennent plus à rendre compte judicieusement de la dynamique des comportements humains émis dans des organisations de plus en plus réticulaires, aux prises avec un éclatement des marchés. À l'évidence, il apparaît nettement que l'approche analytique fonctionnaliste des auteurs convient davantage aux réalités des années 70 qu'à celles d'aujourd'hui.

\section{GÉRARD OUIMET École des Hautes Études Commerciales}

\section{The Changing Workplace: Reshaping Canada's Industrial Relations System by Daniel DRACHE and Harry GLASBEEK, Toronto, James Lorimer \& Company, Publishers, 1992, 306 p., ISBN 1-55028-405-3 (Bond) and ISBN 1-55028-404-5 (PBK).}

Drache and Glasbeek, writing from an unapologetically pro-labour perspective, put forward their proposals for changing both the Canadian industrial relations system and current macroeconomic policy in their book
The Changing Workplace, appropriately subtitled Reshaping Canada's Industrial Relations System. This work is not primarily a study about how Canada's workplaces have changed over the past several decades; rather, their approach 
is a normative one - what should be done to improve the lot of Canadian employees.

The authors note that in an age of increasing global trade and technological innovation, many employees' jobs are at risk. Drache and Glasbeek reject the notion that Canada must participate in multilateral trading blocks in order to maintain economic growth and prosperity. Further, they contend that the Canadian labour movement has been sold a bill of goods and that the present collective bargaining system suits management interests at least as much, if not more, than workers' interests.

Drache and Glasbeek argue that the advent of a Wagner-style collective bargaining regime has been a mixed blessing for organized labour. In chapter three they point to several failings of Canada's collective bargaining system its failure to secure for workers adequate protection against inflation, protection against job loss (whether through contracting out, technological change, or "downsizing") and against temporary layoffs (and consequent income loss). By accepting the imposition of Wagnerstyle bargaining, labour gave up much of its leverage and, essentially, agreed to an institutionalized subordinate position. Why so?

First, bargaining units as defined by labour boards are generally too small and thus lack significant bargaining power. Local unions are primarily concerned with local issues and do not have the energy, the resources, the incentives, or the ability to approach problems such as labour market disparities at a national level. Second, the political authority vested in national labour federations, such as the CLC, is severely attenuated because "central union movement leaders cannot guarantee that their affiliated members will abide by any agreement they make." (p. 53). Third, labour boards, far from being the neutral arbiters of rules that are made by others, are unwilling to be too proactive and thereby upset the basic principles of a "free" market. Quite unwittingly, it seems, labour boards have bought into the notion of maintaining employer power at the expense of employee rights : "They [labour boards] always have been mindful of the need to preserve stability in production and to constrain the capacity of trade unions to challenge the political and economic entente underpinning export-led growth and its attendant competitive model" (p. 97).

In chapter six, Drache and Glasbeek argue that the institutional subordination of labour is nowhere more apparent than in the Canadian system's treatment of the right to strike. The authors argue that, in many cases, this fundamental tool for forcing political and economic reform is severely undermined, all in the name of "stability" in the labour relations arena and for the "protection" of the broader public interest. As the authors put the matter: "The thrust of the statutory regimes has been to bureaucratize the strike and to sanitize the union movement" (p. 99). While the exchange of recognition strikes for a certification process was initially seen by unionists to be a fair trade (and I suspect the vast majority still see it that way), Drache and Glasbeek argue that the cost, namely, the loss of the solidarity inherent in a recognition battle, has proved too high. Further, because the right to strike has been granted as part of a perceived quid pro quo, it must be exercised responsibly (read: infrequently). Pre-Wagner-style bargaining weapons have been taken away and the labour movement has, by and large, willingly accepted its emasculation - strikes cannot be undertaken except in the case of bargaining impasses over economic (rather than broader strategic or political) matters; mid-contract strikes are illegal; strike rights are not constitutionally protected and thus can be lawfully restricted, indeed eliminated, by legislative action. The authors make the case 
that the labour movement should not kowtow to legal restrictions on strike activity because to do so only entrenches labour's subordinate position.

Of course, the loss of mid-contract strike rights is counterbalanced, many would argue, by the legislatively mandated grievance arbitration process. Drache and Glasbeek, in chapter seven, make several very good points about why this tradeoff is not always quite what it seems. While accepting that grievance arbitration has limited some capricious employer actions, nevertheless, it must be recognized that arbitration is slow, expensive, and the outcomes are often uncertain. Drache and Glasbeek particularly question some longstanding arbitral principles - the "obey now, grieve later" rule and the notion that employer discipline stands until set aside. In this latter regard, the authors propose that the system be turned on end; disciplinary sanctions would not be implemented until they passed muster before an arbitrator.

In the final four chapters, the authors focus their attention on broader macroeconomic concerns. In these chapters they discuss systemic problems such as the female wage gap, unemployment, inadequate pension systems and unreasonably dangerous work environments. The authors note that while unionized workers have made some (very modest) gains in these areas, unorganized workers, who comprise the bulk of the Canadian workforce, are even worse off. What is to be done? The authors support broad-based (read: private sector) pay equity programs; mandatory indexing of both private and public pension programs, stricter enforcement of existing safety regulations, granting the right to strike (not the mere individual right to refuse to work) over unsafe work conditions, enriched welfare programs, and an end to free-trade.

Unfortunately, the authors give little, if any, guidance about how their costly agenda might be sold to the public in times in fiscal crisis, other than to suggest that corporations pay higher taxes. This is, I believe, the major failing of the book. It is one thing to make recommendations for reform, however, it is incumbent on those who propose new public expenditures to put a realistic dollar estimate forward as well as a reasonable financing plan. Otherwise, and with good reason, a reform proposal is unlikely to be given any serious consideration. I strongly suspect that this book will not be a catalyst to any "reshaping" of our industrial relations system. And that is a pity as the system is in need of reform.

KENNETH WM. THORNICROFT University of Victoria

\section{Le droit du travail du Québec: théories et pratiques ( $2^{e}$ édition) par Robert P. GaGnoN, Cowansville, Les Éditions Yvon Blais, 1993, 611 p., ISBN 2-89073-899-X.}

Cette excellente synthèse descriptive sur l'état du droit du travail en vigueur décevra néanmoins le lecteur qui aurait apprécié une seconde édition plus critique que la première. L'évolution jurisprudentielle et certaines récentes modifications à la législation soulèvent en effet de nombreuses interrogations qui auraient appelé des mises en situation plus élaborées avant de préciser les sens et portée d'une règle; l'auteur passe trop rapidement.

L'approche retenue et le plan de travail adopté expliquent en bonne partie cette absence d'intérêt pour l'analyse critique. Ainsi l'ouvrage répond à une 